\title{
STUDIES ON HUMAN GROWTH HORMONE. I. A RADIO- IMMUNOASSAY FOR HUMAN GROWTH HORMONE*
}

\author{
By ROBERT D. UTIGER, MARY L. PARKER AND WILLIAM H. DAUGHADAY \\ (From the Metabolism Division, Department of Medicine, Washington University School of \\ Medicine, St. Louis, Mo.)
}

(Submitted for publication June 29, 1961 ; accepted October 5, 1961)

Since highly purified human pituitary growth hormone has become available, much information concerning its metabolic effects has been accumulated. However, simple and specific methods of measuring endogenous levels of human growth hormone have been difficult to achieve. Attempts to assay human growth hormone by injecting whole serum into hypophysectomized rats and measuring the width of the tibial plate have generally failed to show any activity in normal serum, although some acromegalic sera have been found to contain stimulating activity (1-3). More recently, Gemzell (4) assayed extracts of plasma using the tibial-line assay and found up to 12.3 $\mu \mathrm{g}$ growth hormone activity per $\mathrm{ml}$ of plasma in acromegalic subjects. Growth hormone-like activity was also found in plasma extracts from certain patients with diabetes, liver disease, and several other conditions; however, no activity was detected in extracts of normal plasma (5). The variability, insensitivity, and questionable specificity of the tibial assay system have raised doubts as to the significance of these results. In this laboratory, measurement of the serum sulfation factor has proved a useful indicator of growth hormone activity, but it is, nevertheless, not a direct measurement of growth hormone (6).

Immunologic methods for assaying human growth hormone have recently attracted much attention. Li, Moudgal and Papkoff (7) have been able to detect as little as $2.5 \mu \mathrm{g}$ of growth hor-

* Supported by Research Grant A-1526 from the National Institute of Arthritis and Metabolic Diseases, National Institutes of Health, and by an institutional grant to Washington University from the American Cancer Society. Clinical studies were carried out on the Washington University-Barnard Hospital Clinical Research Center, under support of Grant OG-12, Division of General Medical Sciences, National Institutes of Health. Presented in part before the Fifty-third Annual Meeting of the American Society for Clinical Investigation, Atlantic City, N. J., May, 1961. mone by direct precipitation with specific antiserum and reported finding approximately 200 $\mathrm{m} \mu \mathrm{g}$ of growth hormone per $\mathrm{ml}$ in acromegalic serum. Greenspan, Cofell, Lew and Peng (8) have increased the sensitivity of the precipitin reaction by the use of radioiodinated antiserum to human growth hormone, so that as little as $1 \mu \mathrm{g}$ of growth hormone could be detected.

Read and Bryan (9) have utilized the principle of hemagglutination inhibition for the measurement of minute quantities of growth hormone. In their technique, as little as 2 to $20 \mathrm{~m} \mu \mathrm{g}$ of hormone can be dectected. Normal human serum has been found to contain 100 to $600 \mathrm{~m} \mu \mathrm{g}$ per ml by this method, with appropriately higher and lower levels in acromegalic and hypopituitary sera, respectively. Hartog and Fraser (10), using the same technique, have reported somewhat lower levels in normal individuals. The hemagglutination inhibition technique has certain disadvantages in that the manipulations are tedious and not adapted for assaying many samples simultaneously. A number of extraneous factors prevents day-to-day reproducibility, and the evaluation of the complete hemagglutination pattern introduces a subjective judgment.

Isotopic techniques have been applied previously to the study of the reaction of protein hormones with specific antibodies. Frequently, at the concentrations of reactants employed, immunoprecipitation does not occur and special techniques are necessary to separate the hormone-antibody complex from unreacted hormone. Yalow and Berson (11) have achieved this separation by chromatoelectrophoresis in their insulin assay. Another procedure has been immunologic precipitation of the hormone-antibody complex. In their study of sera of diabetic patients containing antibodies that react with heterologous insulin, Skom and Talmage (12) have precipitated insulin- ${ }^{131}$ bound to human $\gamma$-globulin by the ad- 
dition of antihuman $\gamma$-globulin serum. Recently, both chromatoelectrophoresis and immunoprecipitation have proved successful in separating soluble glucagon- $\mathrm{I}^{131}$-antibody complexes from unreacted glucagon- $\mathrm{I}^{131}$ in a sensitive radio-immunoassay (13).

In this paper, the radioiodination of human growth hormone and utilization of the labeled hormone for a highly sensitive radio-immunoassay are described. In this assay the soluble growth hormone-I ${ }^{131}$-antibody complex has been precipitated immunologically by the technique of Skom and Talmage.

\section{MATERIALS AND METHODS}

Human growth hormone (HGH). HGH was prepared from acetone-dried pituitaries by the Raben method (14). The final product was lyophilized and kept at $5^{\circ} \mathrm{C}$ until use. Monkey growth hormone was supplied by Dr. A. E. Wilhelmi. The porcine and bovine hormones were obtained from Dr. Joseph Fisher, Armour Laboratories, Chicago, Ill.

Stock solutions of HGH were prepared in a concentration of $0.2 \mathrm{mg}$ per $\mathrm{ml}$ in $0.01 \mathrm{M}$ phosphate $-0.15 \mathrm{M}$ $\mathrm{NaCl}$ buffer, $\mathrm{pH} 7.2$, and kept at $-14^{\circ} \mathrm{C}$ until use.

Preparation of $\mathrm{HGH}-\mathrm{I}^{131}$. $\mathrm{HGH}$ has been iodinated in a number of ways. At first, iodination was carried out by a modification of the procedure used by Yalow and Berson (11) for iodinating insulin. In this method, which has been described in detail (15), iodide is oxidized to molecular iodine in acid solution with nitrous acid. The iodine is then extracted into chloroform and from the chloroform into alkaline solution containing $\mathrm{HGH}$. Although useful preparations were frequently obtained, other preparations proved to be extensively denatured, perhaps due to trace impurities in the chloroform or the initial oxidation mixture.

More recently, HGH has been iodinated by a modification of the distillation procedure used by Staub, Springs and Elrick in the preparation of glucagon- $I^{131}$ (16). Their apparatus was modified by addition of a $\mathrm{Y}$-joint with Teflon stopcocks to allow refluxing and addition of reagents without disconnecting the reaction vessel (Figure 1). To carry out the iodination 10 to $20 \mathrm{mc}$ carrier-free $\mathrm{NaI}^{131}$ (Union Carbide Nuclear Corp., Oak Ridge, Tenn.), $1.5 \mathrm{ml} 2 \mathrm{~N} \mathrm{H}_{2} \mathrm{SO}_{4}$, and $2.5 \mathrm{ml} \mathrm{H}_{2} \mathrm{O}$ were added to the distilling flask, refluxed gently for $30 \mathrm{~min}$ utes, and allowed to cool. Then $3.0 \mathrm{ml} \mathrm{H}_{2} \mathrm{O}$ and 0.5 to $1.0 \mathrm{ml}$ of a solution containing $0.48 \mathrm{mmole} \mathrm{KI}$ and 0.09 mmole $\mathrm{KIO}_{3}$ per $\mathrm{L}$ were added (in recent iodinations, we have omitted the $\mathrm{KI}$ ). The reaction mixture was next boiled gently until $4.0 \mathrm{ml}$ distillate had accumulated in the collecting tube. Under these conditions, 30 to 60 per cent of the starting radioactivity was recovered in the distillate. After the stopcocks were opened the distillate was added dropwise to a $10 \times 40 \mathrm{~mm}$ tube containing

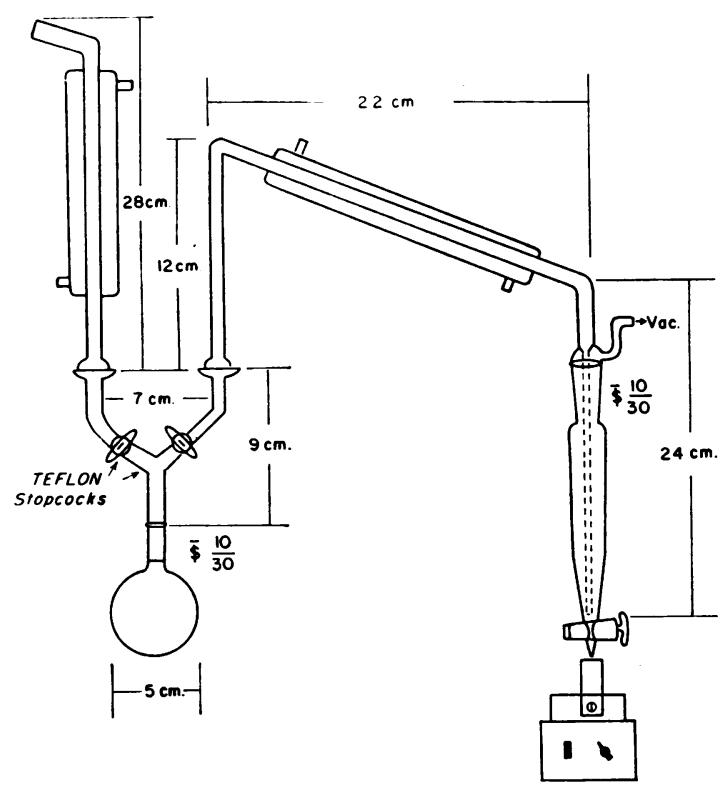

Fig. 1. Distillation apparatus USEd fOR HGH IODINATION.

0.2 to $1.0 \mathrm{mg} \mathrm{HGH}$ in $1.0 \mathrm{ml} 0.2 \mathrm{M}$ borate buffer, $\mathrm{pH}$ 8.0 , in an ice-bath. During the addition of $\mathrm{I}^{131}$ and for 3 minutes thereafter, the growth hormone was mixed with a small Teflon-covered magnet and a magnetic stirrer. The reaction mixture was next transferred to a cellophane bag, one end of which was tied to a rubber serum-bottle cap, and dialyzed for 2 hours against a continuous flow of $0.15 \mathrm{M} \mathrm{NaCl}$ at a rate of $14 \mathrm{~L}$ per hour. Bovine serum albumin (Nutritional Biochemicals, Cleveland, Ohio), sufficient to provide a final concentration of 5 per cent, was injected into the bag after 1 hour. After the second hour of continuous flow dialysis, the HGH- $\mathrm{I}^{131}$ was dialyzed against 2.5 - $\mathrm{L}$ volumes of $0.15 \mathrm{M}$ sodium chloride for 16 to 20 hours. The prolonged dialysis was necessary to remove trichloroacetic acid (TCA)-soluble fragments of $\mathrm{HGH}$. The bovine serum albumin (BSA) was added to minimize radiation damage to the hormone (17) and adsorption of the labeled hormone to glassware (18).

Both iodination procedures have yielded $\mathrm{HGH}-\mathrm{I}^{131}$ with calculated specific activities of up to $5 \mathrm{mc}$ per $\mathrm{mg}$. These preparations were over 97 per cent precipitable in 7.5 per cent TCA and 75 to 85 per cent precipitable immunologically. This discrepancy between TCA and immune precipitability has been attributed to the presence of nondialyzable TCA-precipitable labeled protein fragments which do not react with anti-HGH serum. Much of this probably represents partially degraded $\mathrm{HGH}$, but the presence of labeled protein contaminants of the Raben $\mathrm{HGH}$ has not been completely excluded. After 2 to 3 weeks' storage at $5^{\circ} \mathrm{C}$, the concentration of TCA-soluble $\mathrm{I}^{131}$ increased to 5 to 10 per cent. The calculated I : $\mathrm{GH}$ molecular ratios have ranged from 0.25 to 2.0 . 


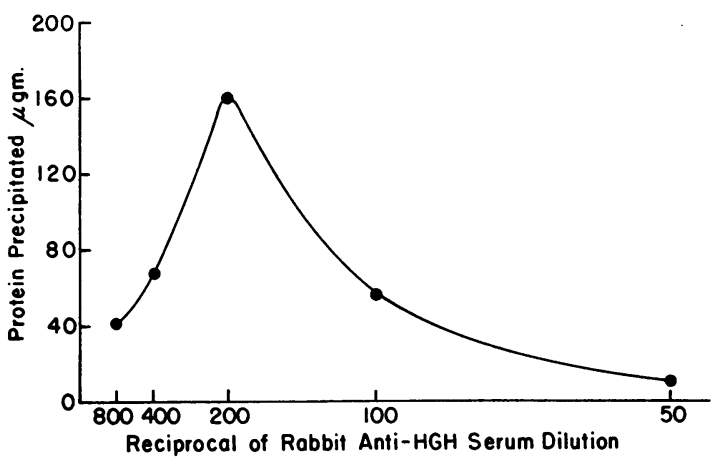

Fig. 2. Precipitation curve obtained with conSTANT AMOUNTS OF GOAT ANTI-RGG SERUM AND VARYING CONCENTRATIONS OF RABBIT ANTI-HGH SERUM. Each tube contained $300 \mu \mathrm{l}$ anti-RGG diluted 1:6, $200 \mu \mathrm{l}$ antiHGH as shown, and $500 \mu 11$ per cent BSA in phosphate-saline buffer. At dilutions of anti-HGH serum greater than $1: 200$, there is anti-RGG excess and maximal precipitation of the anti-HGH serum.

Preparations made with higher I: GH ratios have been found less reactive with antibody.

The iodinated growth hormone was added to normal human serum and subjected to starch block electrophore-

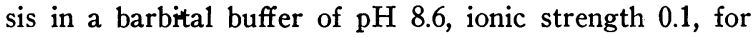
18 hours at 250 v. After electrophoresis, imprints were made and stained. Segments of $1 \mathrm{~cm}$ width were cut, protein was eluted with water, and aliquots of the eluate were counted in a well-type scintillation counter. In this system nearly all radioactivity migrated as a single component with the mobility of the $\alpha$-globulins.

Preparation of anti-HGH serum. The antigen was prepared by emulsifying $2.5 \mathrm{mg} \mathrm{HGH}$ in $2.5 \mathrm{ml}$ saline and $2.5 \mathrm{ml}$ Ramon's (19) or Freund's (20) adjuvant. This mixture was given subcutaneously to New Zealand white rabbits at weekly intervals for 3 weeks. Two weeks after the final injection the rabbits were bled by cardiac puncture. Because of the possibility of trace contamination with other pituitary hormones or with serum proteins which could serve as effective antigens, it is probably undesirable to give booster injections to the same rabbit.

The double diffusion gel technique of Preer (21) was used to test the specificity of our antihuman growth hormone immune sera. Antigens tested were our preparation of $\mathrm{HGH}, \mathrm{HGH}-\mathrm{I}^{131}$, human serum albumin (Squibb), human $\gamma$-globulin (Squibb), and serum from a hypophysectomized patient. Using undiluted anti-HGH antiserum, a single precipitin zone was observed with HGH $(10 \mu \mathrm{g}$ per $\mathrm{ml})$, HGH-I ${ }^{131}$ (10 $\mu \mathrm{g}$ per $\left.\mathrm{ml}\right)$, and with hypophysectomized human serum (diluted 1:10). No precipitin zone was noted with albumin or $\gamma$-globulin.

Preparation of antirabbit $\gamma$-globulin serum (anti-RGG serum). Two injections of $40 \mathrm{mg}$ of rabbit $\gamma$-globulin (Pentex, Inc., Kankakee, Ill.) in $8 \mathrm{ml}$ of adjuvant were given subcutaneously to adult female goats 6 weeks apart, and 2 months later the animals were bled by jugular puncture.
The goat anti-RGG serum was fractionated by precipitation at $1.4 \mathrm{M}\left(\mathrm{NH}_{4}\right)_{2} \mathrm{SO}_{4}$, suspension of the precipitin in water, and dialysis against buffered saline, until the dialysant was free of sulfate. All antisera were stored at $-14^{\circ} \mathrm{C}$ until use and then dilutions of the antisera were prepared with $0.01 \mathrm{M}$ phosphate-0.15 M $\mathrm{NaCl}$ buffer, $\mathrm{pH}$ 7.2.

Titration of goat anti-RGG. A constant volume of goat anti-RGG serum and varying amounts of the rabbit anti-HGH serum were allowed to interreact for 20 to 24 hours at $4^{\circ} \mathrm{C}$. After this period, the precipitates were separated by centrifugation, washed twice with phosphate-saline buffer and then dissolved in $0.25 \mathrm{M}$ acetic acid. The protein concentration was determined by measuring the absorbance in the Beckman spectrophotometer at $278 \mathrm{~m} \mu$ (22). On the basis of such a titration (Figure 2), the amount of anti-HGH serum maximally precipitated by a given amount of anti-RGG was found and the zone of antibody (i.e., anti-RGG) excess was defined.

To confirm the results of the precipitin titration, a second titration was performed employing constant amounts of HGH- ${ }^{131}$, rabbit anti-HGH serum, and varying amounts of goat anti-RGG serum. After incubation and centrifugation, aliquots of the supernatant solution were counted. A parallel titration was run for comparison, using 1 per cent human $\gamma$-globulin as the diluent to evaluate the effect of any cross reaction of the goat antisera and human $\gamma$-globulin.

Titration of $H G H-I^{131}$ preparations and anti-HGH sera. The antigenic reactivity of different $\mathrm{HGH}-\mathrm{I}^{131}$ preparations and the potency of various rabbit sera were determined by the following procedure. A series of tubes was prepared in duplicate with constant amounts of anti$\mathrm{HGH}$ serum and variable amounts of $\mathrm{HGH}-\mathrm{I}^{131}$. All tubes contained at least 0.5 per cent BSA (final concentration) in order to minimize adsorption of radioactivity in glassware. After 2 hours, the anti-RGG serum in excess was added. Eighteen hours later, the per cent of

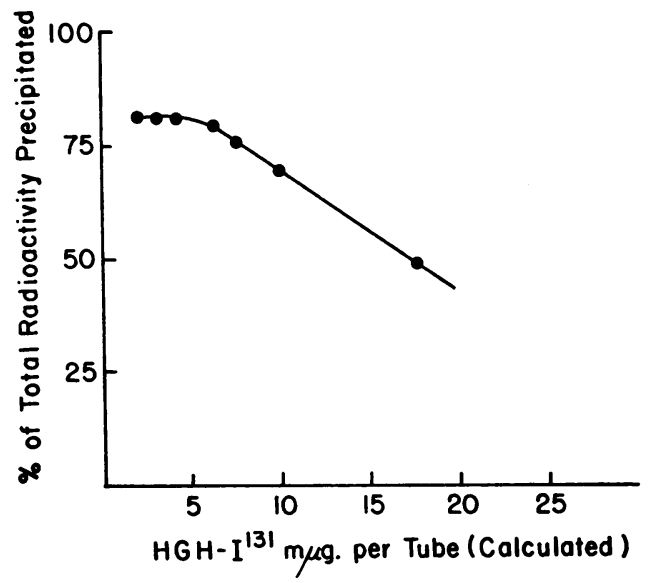

Fig. 3. Titration of an anti-HGH immune SeRUM DILUTED $1: 1,000$ WITH INCREASING CONCENTRATIONS of HGH-I ${ }^{131}$. 

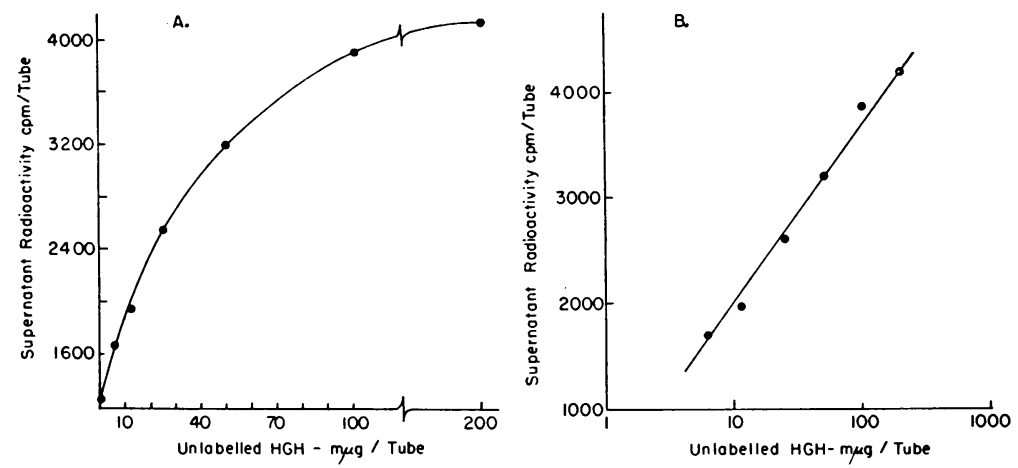

Fig. 4. Standard assay curves showing the Relationship between UNLABELED HGH AND THE TOTAL SUPERNATANT RADIOACTIVITY WITH HGH CONCENTRATION PLOTTED LINEARLY (A) AND LOGARITHMICALLY (B).

total radioactivity precipitated was determined (Figure 3 ) by counting the entire tube and an aliquot of the supernatant solution. At the concentrations of rabbit serum and anti-RGG serum employed, 48 hours' incubation failed to increase the amount of radioactivity precipitated over that obtained at 18 hours. At dilutions of antibody used in the assay, 65 to 70 per cent of the HGH$\mathrm{I}^{131}$ preparations was precipitated. Omission of anti-HGH or anti-RGG serum from the complete system, or substitution of nonimmune rabbit serum for anti-HGH resulted in precipitation of less than 5 per cent of the total radioactivity.

Standard curves and assay of plasma or extracts. The immunoassay depends on ability of unlabeled $\mathrm{HGH}$ to inhibit competitively the binding of $\mathrm{HGH}-\mathrm{I}^{131}$ by anti$\mathrm{HGH}$ serum. The concentration of $\mathrm{HGH}$ in unknown solutions is determined from a standard curve obtained with known concentrations of $\mathrm{HGH}$.

The following volumes and conditions of reaction have proved most satisfactory for $\mathrm{HGH}$ assay. Duplicate tubes were prepared containing: 1) $100 \mu 1$ of $\mathrm{HGH}-\mathrm{I}^{131}$ (1 to $5 \mathrm{~m} \mu \mathrm{g}$, having a radioactivity of about $5,000 \mathrm{cpm}$ ) in 1 per cent BSA in phosphate-saline buffer. 2) $400 \mu 1$ of a solution of 1 per cent BSA in phosphate-saline buffer containing known amounts of $\mathrm{HGH}$ or the sample to be assayed. In each run a blank tube without HGH and 6 to 9 tubes containing from 3 to $400 \mathrm{~m} \mu \mathrm{g} \mathrm{HGH}$ were used. 3) $200 \mu \mathrm{l}$ of anti-HGH serum diluted in phosphatesaline buffer on the basis of prior titration with the $\mathrm{HGH}-\mathrm{I}^{131}$ preparation in use. The dilution of anti-HGH serum used in the assay ranged from 1 to 600 to 1 to 3,200 . When dilutions greater than 1 to 1,200 were used, normal rabbit serum, 1 to 1,200 , was used as the diluent. After 2 hours at $\left.4^{\circ} \mathrm{C}: 4\right) 300 \mu 1$ of anti-RGG serum diluted in phosphate-saline buffer on basis of prior titration was added.

The tubes were shaken and allowed to stand at $5^{\circ} \mathrm{C}$ for 18 hours. The precipitates were then separated by centrifugation and $400-\mu 1$ aliquots of the supernate were transferred to plastic tubes for determination of radioactivity in a well-type scintillation detector.

Extraction of HGH from plasma. Heparinized plasma (serum was equally satisfactory) was extracted by the method of Gemzell (4). Two to $4 \mathrm{ml}$ of plasma was precipitated with an equal volume of 10 per cent TCA. The precipitate was extracted with 3 vol absolute ethanol and the alcohol extract adjusted to $\mathrm{pH} 6.1$ with $0.1 \mathrm{M}$ $\mathrm{NaOH}$. The resulting precipitate was collected by centrifugation, suspended in water, dialyzed for 18 hours, then lyophilized. All operations were done at $5^{\circ} \mathrm{C}$. After lyophilization, the extracts were kept at $5^{\circ} \mathrm{C}$ until assayed, at which time they were dissolved in phosphate-saline buffer to the original volume. With each series of extractions, the recovery of 25 to $500 \mathrm{~m} \mu \mathrm{g} \mathrm{HGH}$ from plasma was determined so that correction for losses could be made. Recovery of the added $\mathrm{HGH}$ has ranged from 40 to 98 per cent and has generally been about 75 per cent. Results given below have all been corrected to 100 per cent recovery. Reproducibility of recovery of $\mathrm{HGH}$ added to a series of plasma samples simultaneously extracted and assayed has varied \pm 12 per cent. Some of the acromegalic plasma used has been kept at $-14^{\circ} \mathrm{C}$ for up to 3 years and still contained measurable activity.

\section{RESULTS}

Effects of $H G H$ on $H G H-I^{131}$ immunoprecipitation. The addition of increasing amounts of $\mathrm{HGH}$ to the assay system led to a progressive rise in the concentration of $\mathrm{HGH}-\mathrm{I}^{131}$ which had not been immunologically precipitated (supernatant $\mathrm{HGH}-\mathrm{I}^{131}$ ) (Figure 4A). In most assays as little as 3 to $6 \mathrm{~m} \mu \mathrm{g}$ of $\mathrm{HGH}$ caused a significant rise in supernatant radioactivity. Although several methods of plotting the assay results have been examined, the most satisfactory was a simple plot of the supernatant radioactivity as a function of the logarithm of the added HGH concentration (Figure 4B). With this type of analysis a straight line function was calculated by the 
method of least squares over the workable portion of the assay curve. If the values at the lower end of this curve fell significantly above this line, an excess of anti-HGH in the system was suspected. The standard curve was used to calculate the HGH concentration of unknown solutions.

Studies with heterologous growth hormones. The ability of pituitary growth hormones from nonhuman sources to inhibit the reaction of HGH-I ${ }^{131}$ with anti-HGH has been examined. Purified porcine and bovine growth hormone, even when added in large amounts, produced virtually no inhibition (Figure 5). In contrast, monkey growth hormone did inhibit the precipitation of HGH-I ${ }^{131}$. The slope of the lines relating the logarithms of growth hormone concentration to supernatant radioactivity for both primate growth hormones is not significantly different $(p>0.5)$. The monkey growth hormone preparation tested was found 40 per cent as effective by weight as the HGH standard preparation in competing with HGH-I ${ }^{131}$ for binding with anti-HGH serum.

Observations on unfractionated plasma. In the present assay system, unfractionated plasma interfered with the precipitation of HGH-I ${ }^{131}$ by its antibody in a nonspecific manner. Evidence for this view is provided by a series of observations on human plasma samples in which there was no

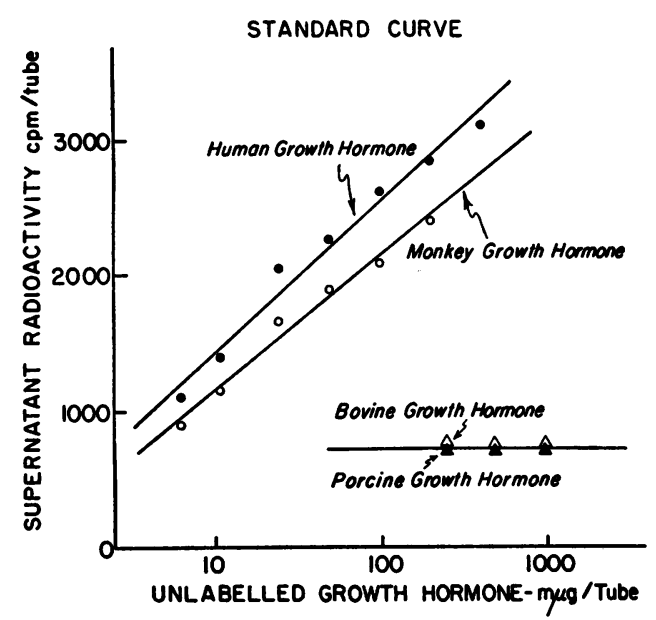

Fig. 5. A COMParison OF THE EFFECTS OF HUMAN, MONKEY, BOVINE, AND PORCINE GROWTH HORMONES ON THE IMMUNOPRECIPITATION OF HGH-I ${ }^{132}$. The assay with bovine and porcine growth hormones was performed at a different time from that with monkey growth hormone, but the standard curves with $\mathrm{HGH}$ of the two assays were comparable.

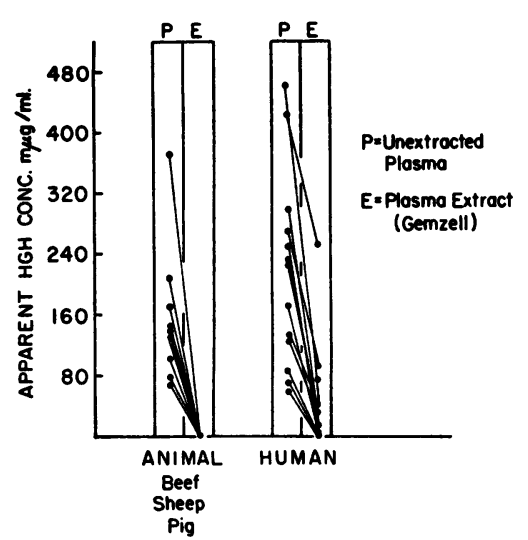

Fig. 6. Removal of inhibitor of HGH Radio-IMMUNOASSAY: ASSAY RESULTS WITH UNEXTRACTED (P) AND EXTRACTED (E) PLASMa. The results on human plasma include samples from normal, acromegalic, and hypopituitary subjects.

relation of the apparent $\mathrm{HGH}$ concentration and the state of pituitary function of the patient (Figure 6). In addition, ovine, porcine, and bovine sera inhibited the precipitation of $\mathrm{HGH}-\mathrm{I}^{131}$ to a major extent (Figure 6), making it appear that these sera contained HGH.

Numbers of observations have been made to define the nonspecific inhibitor of $\mathrm{HGH}-\mathrm{I}^{131}$ immunoprecipitation in unextracted plasma. The inhibitor is not inactivated by heating to $60^{\circ} \mathrm{C}$ for 60 minutes or by prolonged dialysis against water or phosphate-saline buffer. Treating the plasma with $0.01 \mathrm{M}$ periodate according to the method of Burnet and Lind (23), a technique which removes the mucoprotein inhibitor of influenza hemagglutination, failed to remove the nonspecific inhibitor of $\mathrm{HGH}-\mathrm{I}^{131}$ precipitation.

The possibility has been considered that the $\gamma$-globulin of the test samples might cross react with the antirabbit $\gamma$-globulin immune serum, so that there would be insufficient goat antisera to precipitate all the rabbit $\gamma$-globulin present. Although cross reactivity between human $\gamma$-globulin and goat anti-RGG serum does exist, as demonstrated by a precipitin zone in a double diffusion agar system, human $\gamma$-globulin, when added to control assay tubes in amounts comparable to that in undiluted serum, failed to inhibit $\mathrm{HGH}-\mathrm{I}^{131}$ precipitation. Furthermore, neither increasing the amount of anti-RGG serum as much as fourfold nor diluting the test serum as much as tenfold abolished the nonspecific inhibitor. 
There is clear evidence that albumin does not interfere with the immunoreactions used for $\mathrm{HGH}$ assay, in that bovine albumin solutions are used as diluents throughout the procedure and the Gemzell extraction procedure yields a product which is almost exclusively composed of albumin.

The possibility that the nonspecific inhibitor degrades HGH-I ${ }^{131}$ is made unlikely by two observations. First, at the completion of the immunologic reactions no increase in TCA-soluble radioactivity could be demonstrated in tubes containing serum showing nonspecific inhibition. Second, when $\mathrm{HGH}$ was added to unextracted serum, the increment could be measured almost quantitatively by radio-immunoassay.

Extraction of $H G H$ from plasma. The finding that plasma from human beings and other animal species contained a nonspecific inhibitor of the radio-immunoassay prompted an examination of several methods of extracting $\mathrm{HGH}$ from plasma. Fortunately, the procedure of Gemzell (4) completely excluded the nonspecific inhibitor of ovine, bovine, and porcine sera (Figure 6). When this method, using unconcentrated extracts, was applied to 30 plasma samples from normal adults, $\mathrm{HGH}$ activity was detected in 12 . All plasma extracts contained less than $50 \mathrm{~m} \mu \mathrm{g}$ of $\mathrm{HGH}$ even when corrected for losses incurred in the extraction procedure (Figure 7). Extracts from plasma of 22 untreated acromegalic patients had from 15 to $260 \mathrm{~m} \mu \mathrm{g}$ per ml, with a mean of $112 \mathrm{~m} \mu \mathrm{g}$ per $\mathrm{ml}$. Included also in Figure 7 are the results of assays on plasma extracts from a few acromegalic patients after completion of radiation or surgical therapy, whose disease was considered clinically inactive. At the present level of sensitivity little or no HGH was found in the plasma of hypopituitary patients. An exception, however, was one adult patient who had had a craniotomy for craniopharyngioma and who had a serum $\mathrm{HGH}$ assay of $32 \mathrm{~m} \mu \mathrm{g}$ per $\mathrm{ml}$.

\section{DISCUSSION}

The iodination of growth hormone has presented special problems. With the low concentration of hormone protein employed and the high specific activities required for millimicrogram sensitivity of the assay, instability of the labeled hormone has frequently been encountered with direct methods of iodination. It is likely that trace impurities in the original iodine solution or other reagents led to difficulty in using the methods of Yalow and Berson (11). Most of these difficulties are obviated by the distillation technique. It has been observed that much of the degraded hormone exists as relatively small fragments which can be removed by prolonged dialysis. For this reason, the dialysis following iodination has been continued for 20 to 24 hours. Since the labeled hormone has been used solely as an analytical reagent, we have made no attempt to determine its biological activity in experimental animals, but have been content with the demonstration of its reactivity with specific antibody. It is likely that further refinements of existing methods will permit preparation of labeled hormone of higher specific activities.

The sensitivity of the assay system is dependent not only on the specific activity of the labeled growth hormone, but also on the careful adjustment of the concentrations of rabbit anti-HGH and goat anti-RGG sera. A slight excess of $\mathrm{HGH}-\mathrm{I}^{131}$ in respect to anti-HGH must be in the system before added $\mathrm{HGH}$ will effectively compete for the limited number of specific binding sites on the anti-HGH serum. The limit of sensitivity of the assay to date is about $3 \mathrm{~m} \mu \mathrm{g}$. When labeled HGH of higher specific activity becomes available

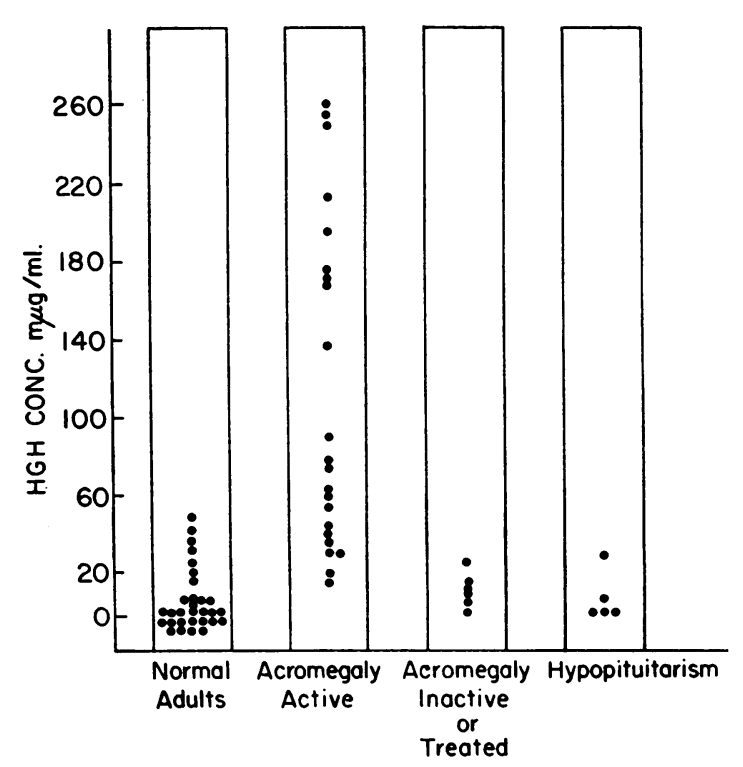

Fig. 7. Results of assays of extracts of human PLASMA. 
and improved methods of counting are devised, greater sensitivities should be obtainable. The anti-RGG must be in excess in respect to the anti$\mathrm{HGH}$ to insure precipitation of all rabbit antibodies and, therefore, of all bound HGH-I ${ }^{131}$.

The use of immunoprecipitation rather than chromatoelectrophoresis to separate free from bound HGH-I ${ }^{131}$ offers certain technical advantages. Large numbers of samples can be assayed simultaneously with a series of tubes containing standard HGH dilutions, and the free HGH-I ${ }^{131}$ is easily sampled for counting after centrifugation. However, the major obstacle to the application of radio-immunoassay to the measurement of $\mathrm{HGH}$ in plasma has been the existence of the nonspecific inhibitor. It is recognized that the extraction procedure used is not a completely satisfactory solution to this problem because it introduces a relatively tedious operation and is subject to significant and variable losses. More information concerning the properties of the nonspecific inhibitor is needed before a simpler procedure for its removal can be designed.

The antigenic specificity of $\mathrm{HGH}$ has been studied and extensively described by previous workers $(7,9,24,25)$. Our observations with radio-immunoprecipitation confirm the information obtained with more orthodox immunologic procedures showing that antisera induced in rabbits by $\mathrm{HGH}$ reacts only with other primate growth hormones and not with growth hormones of other species. Antisera produced by Raben human growth hormone may contain trace amounts of antibodies reacting with serum proteins $(6,9,26,27)$. Our results confirm this general experience. A faint precipitin zone was observed when serum from a hypophysectomized patient was tested against undiluted antiserum in the highly sensitive double diffusion technique. It is doubtful whether the presence of contaminating antibodies in our antisera participated significantly in our assay system, because the concentrations of non-growth hormone antigenic proteins which might be iodinated in our preparations of growth hormone is probably very low. Only a single precipitin zone was evident in the reaction between growth hormone and antisera. Also, in both starch and paper electrophoretic studies the radioactivity of our labeled growth hormone migrated as a single component with a mobility of $\alpha$-globulin. Trace contamination of the human growth hormone used for iodination would lead to significant error in our assay only if selective heavy labeling of the contaminants in preference to the hormone occurred.

The levels of circulating $\mathrm{HGH}$ found in normal individuals by this method have been from 0 to $50 \mathrm{~m} \mu \mathrm{g}$ per $\mathrm{ml}$. Further improvement in the sensitivity of the assay and concentration of extracts will be required before the normal level of hormone can be accurately measured. Nevertheless, it is clear that the concentrations of $\mathrm{HGH}$ detected by this method are less than one-fourth those reported by Read and Bryan (9). The reasons for this discrepancy are unknown. The possibility exists that nonspecific inhibition may operate in the hemagglutination inhibition system and contribute to difficulties with its use $(10,28)$. The current lack of accord of insulin assays may be due in part to differences in the physical state of insulin in the blood (29). Perhaps the divergent results obtained with growth hormone assays may be due to the measurement of different components of the total growth hormone activity of plasma.

\section{SUMMARY}

Methods for the radioiodination of human growth hormone which yield labeled hormone of both high specific radioactivity and reactivity with specific antibodies are described. With these preparations a radio-immunoassay for human growth hormone, capable of detecting 3 to $6 \mathrm{~m} \mu \mathrm{g}$ human growth hormone, has been developed.

Bovine, ovine, and porcine growth hormone did not prevent the immunoprecipitation of iodinated human growth hormone in this assay, but monkey growth hormone inhibited iodinated human growth hormone precipitation.

Human and animal sera were found to contain a nonspecific inhibitor of the immunoassay system which can be excluded by an extraction procedure that permits the extraction of growth hormone.

Circulating levels of growth hormone determined by radio-immunoassay in normal adults ranged from 0 to $50 \mathrm{~m} \mu \mathrm{g}$ per $\mathrm{ml}$. Levels of 15 to $250 \mathrm{~m} \mu \mathrm{g}$ per $\mathrm{ml}$ were found in a series of untreated acromegalic subjects while values after treatment ranged from 0 to $27 \mathrm{~m} \mu \mathrm{g}$ per $\mathrm{ml}$. 


\section{ACKNOWLEDGMENT}

The authors wish to thank Dr. Joseph D. Fisher of Armour Laboratories for his contributions to this project.

\section{REFERENCES}

1. Kinsell, L. W., Michaels, G. D., Li, C. H., and Larsen, W. E. Studies in growth. I. Interrelationship between pituitary growth factor and growth-promoting androgens in acromegaly and gigantism; quantitative evaluation of bone and soft tissue growth in acromegaly and gigantism. J. clin. Endocr. 1948, 8, 1013.

2. Segaloff, A., Komrad, E. L., Flores, A., Segaloff, A., and Hardesty, M. The growth hormone content of human plasma. Endocrinology 1955, 57, 527.

3. Gemzell, C. A., Heijkenskjöld, F., and Ström, L. A method for demonstrating growth hormone activity in human plasma. J. clin. Endocr. 1955, 15, 537.

4. Gemzell, C. A. Demonstration of growth hormone in human plasma. J. clin. Endocr. 1959, 19, 1049.

5. Forsman, O., and Gemzell, C. A. Plasma levels of growth hormone in patients with diabetes mellitus, hypercholesterolaemia and liver diseases. Acta endocr. (Kbh.) 1959, 32, 480.

6. Daughaday, W. H., Salmon, W. D., Jr., and Alexander, F. Sulfation factor activity of sera from patients with pituitary disorders. J. clin. Endocr. 1959, 19, 743.

7. Li, C. H., Moudgal, N. R., and Papkoff, H. Immunochemical investigations of human pituitary growth hormone. J. biol. Chem. 1960, 235, 1038.

8. Greenspan, F. S., Cofell, J. C., Lew, W., and Peng, C. T. Assay of human growth hormone with $\mathrm{I}^{131}$ labeled antibody. Clin. Res. 1961, 9, 99.

9. Read, C. H., and Bryan, G. T. The immunological assay of human growth hormone. Recent Progr. Hormone Res. 1960, 16, 187.

10. Hartog, M., and Fraser, R. The immunological assay of growth hormone in human serum. J. Endocr. 1961, 22, 101.

11. Yalow, R. S., and Berson, S. A. Immunoassay of endogenous plasma insulin in man. J. clin. Invest. 1960, 39, 1157.

12. Skom, J. S., and Talmage, D. W. Nonprecipitating insulin antibodies. J. clin. Invest. 1958, 37, 783.

13. Unger, R. H., Eisentraut, A. M., McCall, M. S., Keller, S., Lanz, H. C., and Madison, L. L. Glucagon antibodies and their use for immunoassay for glucagon. Proc. Soc. exp. Biol. (N. Y.) 1959, 102,621 .
14. Raben, M. S. Preparation of growth hormone from pituitaries of man and monkey. Science 1957, 125, 883.

15. Salmon, S., Utiger, R., Parker, M., and Reichlin, S. The fate of ${ }^{131}$-labeled human growth hormone in the rabbit. In preparation.

16. Staub, A., Springs, V., and Elrick, H. An improved technique for labelling proteins with $\mathrm{I}^{131}$. Int. J. appl. Radiat. 1957, 2, 59.

17. Berson, S. A., and Yalow, R. S. Radiochemical and radiobiological alterations of $I^{131}$-labeled proteins in solution. Ann. N. Y. Acad. Sci. 1957, 70, 56.

18. Hill, J. B. The adsorption of $\mathrm{I}^{131}$ insulin to glass. Endocrinology 1959, 65, 515.

19. Ramon, G., Lemetayer, E., and Richou, R. De l'influence de diverses substances ajoutés à l'antigène anatoxique dans la production de l'immunité antitoxique. Rev. Immunol. 1935, 1, 199.

20. Freund, J., Lipton, M. M., and Thompson, G. E. Aspermatogenesis in the guinea pig induced by testicular tissue and adjuvants. J. exp. Med. 1953, 97, 711.

21. Preer, J. R., Jr. A quantitative study of a technique of double diffusion in agar. J. Immunol. 1956, 77, 52.

22. Gitlin, D. Use of ultraviolet absorption spectroscopy in the quantitative precipitin reaction. J. Immunol. 1949, 62, 437.

23. Burnet, F. M. and Lind, P. E. Recombination of influenza viruses in the de-embryonated egg. Aust. J. exp. Biol. med. Sci. 1954, 32, 145.

24. Fishman, J., McGarry, E. E., and Beck, J. C. Studies using anterior pituitary hormones as antigens. Proc. Soc. exp. Biol. (N.Y.) 1959, 102, 446.

25. Hayashida, T., and $\mathrm{Li}, \mathrm{C} . \mathrm{H}$. A comparative immunological study of pituitary growth hormone from various species. Endocrinology 1959, 65, 944.

26. Grumbach, M. M., Kaplan, S. L., and Solomon, S. Immunochemical observations on antisera to purified human growth hormone. Nature (Lond.) 1960, 185, 170.

27. Boucher, B. J. Immunoelectrophoresis of human sera with antiserum to Raben growth hormone. Nature (Lond.) 1960, 188, 1025.

28. McGarry, E. E., Ballantyne, A., and Beck, J. C. Effect of human serum on the reaction between hormones and their specific antisera (abstract no. 159). Endocrine Society, 43rd Annual Meeting, New York, 1961.

29. Antoniades, H. N. Studies on the state of insulin in blood: The state and transport of insulin in blood. Endocrinology 1961, 68, 7. 